\title{
ANALISIS FAKTOR PENYEBAB PENUMPUKAN PENCAIRAN DANA APBN PADA AKHIR TAHUN ANGGARAN
}

\author{
Fandi Zaenudinsyah \\ Sekretariat Direktorat Jenderal Perbendaharaan \\ Alamat Korespondensi: fanzaen@gmail.com
}

\section{INFORMASI ARTIKEL}

Diterima Pertama

24 Mei 2016

Dinyatakan Diterima

15 Juli 2016

KATA KUNCI:

Fiscal Policy, National Budget, Government Expenditures, Fund Disbursement.

KLASIFIKASI JEL:

D2, H57, 021, 038

\begin{abstract}
ABSTRAK
Central government expenditures as the largest component of state expenditures have an important role in determining national output and affecting allocation and efficiency of economic resources. The increase of state expenditures, both for central government expenditures and transfer to local governments, are ideally followed by responsive budget absorption pattern. The high remaining budget at the end of the year indicates that the budget implementation is not optimal, which could lead to economic losses. This low budget absorption pattern has also occurred at the spending units at the State Treasury Service Office (KPPN) Jakarta V. This study aims to determine the factors that cause a low budget absorption pattern of the state budget (APBN) at the end of the fiscal year at KPPN Jakarta V. This study used method of data analysis in the form of factor analysis. The results show that the low budget absorption pattern of the state funds at the end of the fiscal year is caused by eight factors, namely treasury administration, procurement implementation, budget planning, technical support requirements, procurement schedule, human resources, competencies, and job rotation.
\end{abstract}

Belanja pemerintah pusat sebagai komponen terbesar belanja negara memiliki peran penting dalam menentukan output nasional dan mempengaruhi alokasi dan efisiensi sumber daya ekonomi. Peningkatan belanja negara, baik belanja pemerintah pusat maupun transfer ke daerah, idealnya diikuti dengan pola penyerapan yang responsive. Penyerapan anggaran yang masih menumpuk pada akhir tahun mengindikasikan bahwa pelaksanaan anggaran belum optimal, bahkan dapat menyebabkan kerugian negara secara ekonomis. Penumpukan pencairan dana tersebut juga terjadi pada Satuan Kerja lingkup Kantor Pelayanan Perbendaharaan Negara (KPPN) Jakarta V. Penelitian ini bertujuan untuk mengetahui faktor-faktor penyebab penumpukan pencairan dana APBN pada akhir tahun anggaran. Penelitian ini menggunakan metode analisis data berupa analisis faktor. Hasil penelitian menunjukkan bahwa penumpukan pencairan dana APBN pada akhir tahun anggaran pada Satuan Kerja lingkup KPPN Jakarta V disebabkan oleh delapan faktor, yaitu administrasi perbendaharaan, pelaksanaan pengadaan, perencanaan anggaran, persyaratan teknis pendukung, jadwal pengadaan, sumber daya manusia, kompetensi, dan mutasi pejabat. 


\section{PENDAHULUAN}

\subsection{Latar Belakang}

Pasal 11 ayat (4) Undang-Undang Nomor 17 Tahun 2003 tentang Keuangan Negara menjelaskan bahwa penggunaan belanja negara adalah untuk keperluan penyelenggaraan tugas pemerintah pusat dan perimbangan keuangan antara pemerintah pusat dan daerah. Laporan Keuangan Pemerintah Pusat Tahun 2013 Audited pada bagian Catatan atas Laporan Keuangan menjelaskan bahwa belanja pemerintah pusat sebagai komponen terbesar dari belanja negara berperan sangat penting dalam pencapaian tujuan nasional. Hal ini karena besaran dan komposisi belanja pemerintah pusat dalam operasi fiskal pemerintah berdampak signifikan pada permintaan agregat yang menentukan output nasional dan mempengaruhi alokasi dan efisiensi sumber daya ekonomi.

Belanja pemerintah pusat berkaitan dengan ketersediaan dana dalam menjalankan fungsi alokasi, distribusi dan stabilisasi. Belanja Negara, baik Belanja Pemerintah Pusat maupun Transfer ke Daerah, cenderung meningkat dari tahun ke tahun. Laporan Keuangan Pemerintah Pusat Tahun 2013 Audited pada bagian Catatan atas Laporan Keuangan menjelaskan bahwa peningkatan belanja pemerintah berimplikasi terhadap makro ekonomi sektor riil. Implikasi tersebut berupa pengaruh terhadap konsumsi, investasi dan pertumbuhan ekonomi nasional, serta kesejahteraan masyarakat. Selain itu, laporan tersebut juga menjelaskan bahwa peningkatan belanja idealnya diikuti dengan pola penyerapan dana Anggaran Pendapatan dan Belanja Negara (APBN) yang responsif sebagai stimulus pertumbuhan ekonomi. Penyerapan anggaran yang masih menumpuk pada akhir tahun mengindikasikan bahwa pelaksanaan anggaran belum optimal.

Penyerapan anggaran yang lambat dapat mengakibatkan kerugian negara secara ekonomis. ${ }^{1}$ Rencana penarikan dana pada DIPA mencerminkan kebutuhan dana pengguna anggaran, sehingga Bendahara Umum Negara (BUN) dalam hal ini adalah Menteri Keuangan, harus menyiapkan kebutuhan dana tersebut. Apabila Rekening Kas Umum Negara (R-KUN) tidak mencukupi kebutuhan dana, BUN mengusahakan pembiayaan dari berbagai sumber. Pembiayaan seringkali memunculkan beban bunga yang harus ditanggung pemerintah. Dengan demikian, tidak terserapnya dana yang telah disediakan akan menyebabkan kerugian ekonomis akibat menanggung beban bunga dan adanya idle

1 Hendris Herriyanto, Faktor-Faktor yang Mempengaruhi Keterlambatan Penyerapan Anaggaran Belanja pada Satuan Kerja Kementerian/ Lembaga di Wilayah Jakarta (Jakarta: Fakultas Ekonomi. Universitas Indonesia, 2012), hlm. 2. cash pada rekening pemerintah. Pemerintah telah melakukan berbagai usaha untuk menyikapi lambatnya penyerapan anggaran. Namun demikian, usaha-usaha tersebut belum mampu mengeliminasi masalah penumpukan pencairan dana APBN di akhir tahun anggaran secara keseluruhan.

Kantor Pelayanan Perbendaharaan Negara (KPPN), instansi vertikal Direktorat Jenderal Perbendaharaan, Kementerian Keuangan, yang bertugas melaksanakan penyaluran pembiayaan atas beban anggaran kepada Satuan Kerja (Satker) Kementerian/ Lembaga dan Satuan Kerja Perangkat Daerah, umumnya mengetahui fenomena lambatnya penyerapan anggaran dan menumpuk pencairan dana anggaran pada akhir tahun. Satker melaksanakan kegiatan pemerintahan tertentu yang dibiayai dari dana tersebut. Studi kasus yang dilakukan pada KPPN Jakarta V menunjukan telah terjadi permasalahan penyerapan anggaran yang lambat, terutama pada belanja barang dan belanja modal. Hal ini sebagaimana ditunjukkan pada Grafik 1. Belanja Bantuan Sosial tampak meningkat tajam pada Grafik tersebut, tetapi peningkatannya disebabkan oleh adanya revisi penurunan pagu yang signifikan, sehingga persentase penyerapan jenis belanja tersebut kurang representatif.

Grafik 1. Trend Penyerapan APBN pada Satker Lingkup KPPN Jakarta V Tahun 2014

(Data Triwulan dan Tidak Akumulatif)

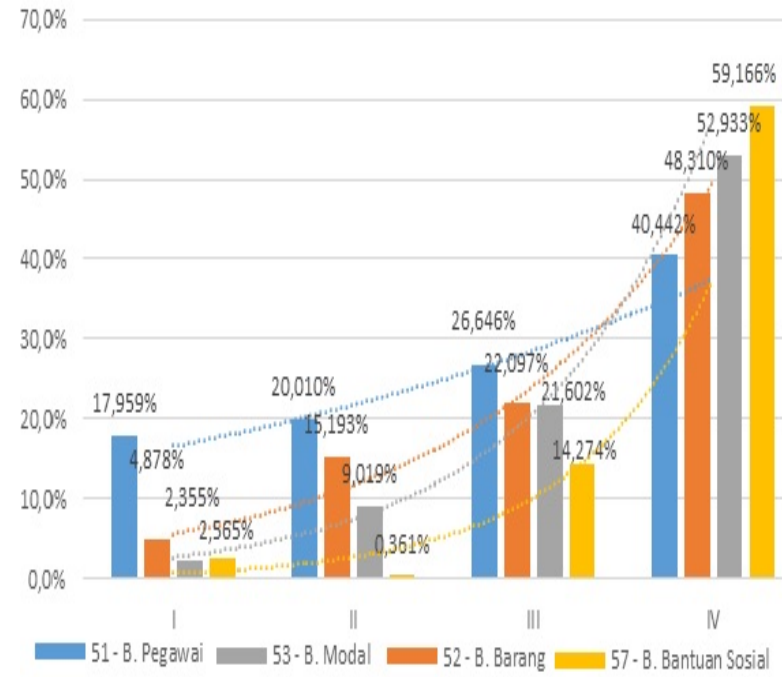

Sumber: Laporan Realisasi Anggaran Tahun 2014 Per Jenis Belanja KPPN Jakarta V

Terdapat penelitian-penelitian yang telah dilakukan untuk mengetahui faktor-faktor yang menyebabkan penumpukan pencairan dana APBN pada akhir tahun anggaran dengan objek studi Satker lingkup pembayaran berbagai KPPN. Namun demikian, belum ada di antara penelitian-penelitian tersebut yang menjadikan Satker lingkup KPPN Jakarta V sebagai objek penelitian secara khusus. Oleh karena itu, melalui penelitian ini, penulis ingin 
mengetahui faktor- faktor yang menyebabkan penumpukan pencairan dana APBN pada akhir tahun anggaran pada Satker lingkup KPPN Jakarta V.

\subsection{Ruang Lingkup}

Penulis membatasi ruang lingkup penelitian ini dengan memfokuskan penelitian pada penumpukan pencairan dana APBN berupa belanja pemerintah pusat khususnya belanja barang dan belanja modal. Selain itu, penulis membatasi responden penelitian ini pada Kuasa Pengguna Anggaran (KPA) atau Pejabat Pembuat Komitmen (PPK) untuk setiap Satker lingkup KPPN Jakarta V.

\subsection{Masalah Penelitian}

Masalah dalam penelitian ini adalah: Faktorfaktor apa yang menjadi penyebab penumpukan pencairan dana APBN pada akhir tahun anggaran pada Satker lingkup KPPN Jakarta V?

\subsection{Tujuan penelitian}

Penelitian ini bertujuan untuk mengetahui faktor-faktor penyebab penumpukan pencairan dana APBN pada akhir tahun anggaran pada Satker lingkup KPPN Jakarta V.

\subsection{Manfaat Penelitian}

Penulis mengharapkan penelitian ini dapat bermanfaat bagi pemerintah, khususnya Kementerian Keuangan, sebagai bahan informasi dalam pertimbangan penyusunan kebijakan untuk mengatasi penyebab penumpukan pencairan dana APBN pada akhir tahun anggaran. Selain itu, penulis juga mengharapkan penelitian ini dapat menjadi bahan referensi pada studi literatur bidang menajamen keuangan, khususnya sektor pemerintah, untuk kepentingan pengembangan dunia akademis dimasa mendatang terkait dengan penyebab penumpukan pencairan dana APBN pada akhir tahun anggaran.

\section{KERANGKA TEORI}

\subsection{Anggaran}

Anggaran (budget) adalah komponen kunci dalam perencanaan keuangan untuk masa depan, yang memuat identifikasi tujuan dan tindakan yang diperlukan untuk mencapainya. ${ }^{2}$ Penganggaran merupakan proses menyusun atau menghasilkan anggaran dan memiliki manfaat, yaitu memaksa manajer merencanakan, memberikan informasi yang dapat digunakan untuk meningkatkan pembuatan keputusan, memberikan sebuah standar untuk mengevaluasi kinerja, dan menguatkan

2 Don R. Hansen dan M. Mowen Maryanne, Managerial Accounting. 8th edition, (Ohio: Thomson Learning South-Western, 2007), hlm. 316. komunikasi dan koordinasi ${ }^{3}$. Badan Pendidikan dan Pelatihan Keuangan (BPPK) menjelaskan bahwa anggaran adalah rencana keuangan yang merupakan perkiraan tentang apa yang akan dilakukan di masa yang akan datang dan memuat paparan rencana pengeluaran yang didasarkan pada ekspektasi pendapatan dan rencana pengeluaran tersebut sebaiknya mengindikasikan juga urutan prioritas dan ekspektasi kualitas dan kuantitas layanan4.

\subsection{Anggaran Pendapatan dan Belanja Negara (APBN)}

Pasal 1 Undang-Undang Nomor 17 Tahun 2003 tentang Keuangan Negara menyebutkan bahwa Anggaran Pendapatan dan Belanja Negara (APBN) adalah rencana keuangan tahunan pemerintah yang disetujui oleh Dewan Perwakilan Rakyat (DPR). APBN, perubahan APBN, dan pertanggungjawaban pelaksanaan APBN setiap tahun ditetapkan dengan undang-undang. APBN memiliki fungsi otorisasi, perencanaan, pengawasan, alokasi, distribusi, dan stabiliasasi. Tahun anggaran meliputi masa satu tahun, dimulai dari tanggal 1 Januari sampai dengan tanggal 31 Desember. Penyusunan APBN setiap tahun adalah dalam rangka penyelenggaraan fungsi pemerintahan untuk mencapai tujuan bernegara.

Pasal 11 Undang- Undang Nomor 17 Tahun 2003 menjelaskan bahwa APBN merupakan wujud pengelolaan keuangan negara yang ditetapkan setiap tahun dengan undang- undang yang terdiri atas anggaran pendapatan, anggaran belanja, dan pembiayaan. Pasal 12 UU No. 17 Tahun 2003 menyatakan bahwa APBN disusun sesuai kebutuhan penyelenggaraan pemerintahan dan kemampuan menghimpun pendapatan negara. Kebijakan fiskal yang diimplementasikan melalui APBN memiliki peran penting dan strategis dalam mempengaruhi perekonomian, terutama dalam upaya mencapai target-target pembangunan nasional dan berkaitan dengan tiga fungsi utama pemerintah, yaitu fungsi alokasi, fungsi distribusi, dan fungsi stabilisasi ${ }^{5}$.

Direktorat Jenderal Anggaran menyatakan bahwa siklus APBN merupakan rangkaian kegiatan yang berawal dari perencanaan dan penganggaran sampai dengan pertanggungjawaban APBN yang setiap tahun anggaran berulang dengan tetap dan teratur6. Siklus tersebut adalah sebagai berikut:

3 Ibid, hlm.317.

4 Tim Penyusun BPPK, Dasar-Dasar Keuangan Publik, (Jakarta: Badan Pendidikan dan Pelatihan Keuangan (BPPK), 2004), hlm. 71

5 Kementerian Keuangan, Laporan Keuangan Pemerintah Pusat Tahun 2013-Audited, (Jakarta: Kementerian Keuangan, 2014), hlm. 20.

6 Kementerian Keuangan, Pokok-Pokok Siklus APBN di Indonesia: Penyusunan Konsep Kebijakan dan Kapasitas Fiskal Sebagai Langkah Awal, (Jakarta: Direktorat Jenderal Anggaran, 2014), hlm. 7. 
1. Perencanaan dan Penganggaran APBN (Januari-Juli);

2. Pembahasan APBN (Agustus-Oktober);

3. Penetapan APBN (akhir Oktober);

4. Pelaksanaan APBN (sejak Januari);

5. Pelaporan dan Pencatatan APBN;

6. Pemeriksaan dan Pertanggungjawaban APBN.

\subsection{Daftar isian Pelaksanaan Anggaran (DIPA)}

Pasal 1 Peraturan Menteri Keuangan (PMK) No. 171/PMK.02/2013 tentang Petunjuk Penyusunan dan Pengesahan Daftar Isian Pelaksanan Anggaran menjelaskan bahwa, DIPA sebagai dokumen pelaksanaan anggaran yang disusun oleh Pengguna Anggaran/ Kuasa Pengguna Anggaran yang berlaku 1 (satu) tahun anggaran dan memuat informasi satuansatuan terukur yang berfungsi sebagai dasar pelaksanaan kegiatan bagi Satker dan dasar pencairan dana/ pengesahan bagi Bendahara Umum Negara/ Kuasa Bendahara Umum Negara. PMK No. 171/PMK.02/2013 juga menyatakan bahwa pagu dalam DIPA merupakan batas pengeluaran tertinggi yang tidak boleh dilampaui dan pelaksanaannya harus dapat dipertanggungjawabkan.

Berdasarkan pengertian tersebut, DIPA merupakan kesatuan antara rincian rencana kerja dan penggunaan anggaran yang disusun oleh Kementerian Negara/ Lembaga dan disahkan oleh Bendahara Umum Negara (BUN). Dengan demikian, DIPA menunjukkan perikatan Kementerian Negara/ Lembaga atau satuan kerja sebagai Pengguna/ Kuasa Pengguna Anggaran untuk menyelenggarakan kegiatan pemerintahan yang didanai penyelenggaraanya oleh APBN. Dengan kata lain, DIPA menjadi dasar melakukan tindakan yang mengakibatkan terjadinya pengeluaran negara dengan pencairan dana APBN untuk menyelenggarakan kegiatan pemerintahan.

PMK Nomor 171/PMK.02/2013 membagi DIPA menjadi 2 (dua), yaitu DIPA Bagian Anggaran Kementrian Negara/ Lembaga (DIPA BA K/L) dan DIPA Bagian Anggaran Bendaraha Umum Negara (DIPA BA BUN). DIPA BA K/L terdiri atas DIPA Induk dan DIPA Petikan. DIPA Induk merupakan akumulasi dari DIPA per satker yang disusun oleh Pengguna Anggaran menurut Unit Eselon I Kementerian Negara/ Lembaga, sedangkan DIPA Petikan merupakan DIPA per satker yang dicetak secara otomatis melalui sistem yang digunakan sebagai dasar pelaksanaan kegiatan satker dan pencairan dana/ pengesahan bagi BUN/ Kuasa BUN dan merupakan kesatuan yang tidak terpisahkan dari DIPA Induk. Susunan DIPA Induk dan DIPA Petikan dinyatakan dalam PMK tersebut sebagai berikut:

1. DIPA Induk terdiri atas Lembar Surat Pengesahan DIPA Induk, Halaman I yang memuat Informasi Kinerja dan Anggaran Program, Halaman II yang memuat Rincian Alokasi Anggaran per Satker, dan Halaman III yang memuat Rencana Penarikan Dana dan Perkiraan
Penerimaan.

2. DIPA Petikan terdiri atas Lembar Surat Pengesahan DIPA Petikan, Halaman IA yang memuat Informasi Kinerja dan Halaman IB yang memuat Sumber Dana, Halaman II yang memuat Rincian Pengeluaran, Halaman III yang memuat Rencana Penarikan Dana dan Perkiraan Penerimaan, dan Halaman IV memuat Catatan.

Pasal 38 Peraturan Pemerintah No. 45 Tahun 2013 tentang Tata Cara Pelaksanaan Anggaran Pendapatan dan Belanja Negara menjelaskan bahwa DIPA dapat direvisi karena 4 (empat) alasan sebagai berikut:

1. Revisi DIPA karena alasan administratif meliputi perubahan kantor bayar, perubahan jenis belanja sebagai akibat kesalahan penggunaan akun sepanjang dalam peruntukan dan sasaran yang sama, dan perubahan lainnya akibat kekeliruan pencantuman dalam DIPA;

2. Revisi DIPA karena alasan alokatif meliputi penambahan atau pengurangan alokasi pagu anggaran dan perubahan atau pergeseran rincian pagu anggaran. Namun, revisi DIPA karena alasan alokatif tersebut tidak dapat mengurangi pagu anggaran yang dialokasikan untuk belanja pegawai, kecuali untuk pergeseran pagu anggaran belanja pegawai antar DIPA dalam lingkup Kementerian Negara/ Lembaga yang sama;

3. Revisi DIPA karena perubahan rencana penarikan dana dilakukan dalam rangka menyesuaikan dengan realisasi belanja dan perubahan rencana Kegiatan;

4. Revisi DIPA karena perubahan rencana penerimaan dana dilakukan dalam rangka menyesuaikan dengan realisasi Penerimaan Negara dan perubahan target Penerimaan Negara.

\subsection{Belanja Pemerintah Pusat}

Belanja Negara dalam postur APBN terdiri atas Belanja Pemerintah Pusat dan Transfer ke Daerah. Laporan Realisasi Anggaran pada Laporan Keuangan Pemerintah Pusat Tahun $2013 \quad$ (Audited) menunjukkan bahwa Belanja Pemerintah Pusat dikelompokkan menjadi beberapa jenis belanja, yaitu: Belanja Pegawai, Belanja Barang, Belanja Modal, Pembayaran Bunga Utang, Subsidi, Belanja Hibah, Belanja Bantuan Sosial, dan Belanja Lain-lain. ${ }^{7}$ Setiap jenis belanja pemerintah pusat tersebut dijelaskan pada Bab II Bagian Penjelasan Segmen Bagan Akun Standar PMK Nomor 214/PMK.05/2013 tentang Bagan Akun Standar sebagai berikut:

1. Belanja Pegawai merupakan pengeluaran sebagai kompensasi terhadap pegawai dalam bentuk uang atau barang, yang harus dibayarkan kepada pegawai pemerintah baik dalam maupun luar

7 Kementerian Keuangan, Laporan Keuangan Pemerintah Pusat Tahun 2013-Audited, hlm. 8. 
negeri, kepada pejabat negara, Pegawai Negeri Sipil (PNS) dan pegawai yang dipekerjakan oleh pemerintah yang belum berstatus PNS, sebagai imbalan atas pekerjaan yang telah dilaksanakan dalam rangka mendukung tugas fungsi unit organisasi pemerintah selama periode tertentu, kecuali pekerjaan yang berkaitan dengan pembentukan modal.

2. Belanja Barang merupakan pengeluaran untuk menampung pembelian barang dan jasa yang habis pakai untuk memproduksi barang dan jasa baik yang dipasarkan maupun tidak dipasarkan serta pengadaan barang dan jasa yang dimaksudkan untuk diserahkan atau dijual kepada masyarakat dan belanja perjalanan. Belanja ini terdiri atas belanja barang dan jasa, belanja pemeliharaan, belanja perjalanan dinas, belanja barang BLU dan belanja barang untuk diserahkan kepada masyarakat.

3. Belanja Modal merupakan pengeluaran anggaran guna memperoleh atau menambah aset tetap dan/ atau aset lainnya yang memberi manfaat ekonomis lebih dari satu periode akuntansi $(12$ bulan) serta melebihi batasan nilai minimum kapitalisasi aset tetap atau aset lainnya yang ditetapkan pemerintah. Aset tetap tersebut digunakan untuk operasional kegiatan satker atau digunakan oleh masyarakat umum dan akan dicatat di dalam Neraca satker K/L.

4. Belanja Pembayaran Bunga Utang/Kewajiban merupakan pengeluaran pemerintah untuk pembayaran bunga yang dilakukan atas kewajiban penggunaan pokok utang baik utang dalam negeri maupun utang luar negeri yang dihitung berdasarkan posisi pinjaman jangka pendek atau jangka panjang. Selain itu, belanja pembayaran bunga utang juga digunakan untuk pembayaran denda/ biaya lain terkait pinjaman dan hibah baik dalam negeri maupun luar negeri, serta imbalan bunga. Jenis belanja ini khusus digunakan dalam kegiatan dari Bagian Anggaran Bendahara Umum Negara.

5. Belanja Subsidi merupakan pengeluaran atau alokasi anggaran yang diberikan kepada perusahaan negara, lembaga pemerintah, atau pihak ketiga lainnya yang memproduksi, menjual, mengekspor, atau mengimpor barang dan jasa untuk memenuhi hajat hidup orang banyak sedemikian rupa sehingga harga jualnya dapat dijangkau oleh masyarakat. Belanja ini antara lain digunakan untuk penyaluran subsidi kepada masyarakat melalui perusahaan negara dan/ atau perusahaan swasta yang diberikan oleh Menteri Keuangan selaku Bendahara Umum Negara.

6. Belanja Hibah merupakan pengeluaran pemerintah berupa transfer dalam bentuk uang/ barang/ jasa, yang dapat diberikan kepada pemerintah negara lain, organisasi internasional, pemerintah daerah, atau kepada perusahaan negara/ daerah yang secara spesifik telah ditetapkan peruntukannya, bersifat tidak wajib dan tidak mengikat, yang dilakukan dengan naskah perjanjian antara pemerintah selaku pemberi hibah dan penerima hibah, serta tidak terus menerus kecuali ditentukan lain dalam peraturan perundang-undangan.

7. Belanja Bantuan Sosial merupakan pengeluaran berupa transfer uang, barang, atau jasa yang diberikan oleh pemerintah kepada masyarakat guna melindungi dari kemungkinan terjadinya risiko sosial dan meningkatkan kemampuan ekonomi dan/ atau kesejahteraan masyarakat.

8. Belanja Lain-lain merupakan pengeluaran/ belanja pemerintah pusat yang sifat pengeluarannya tidak dapat diklasifiksikan ke dalam pos- pos pengeluaran di atas. Pengeluaran ini bersifat tidak biasa dan tidak diharapkan berulang seperti penanggulangan bencana alam, bencana sosial, dan pengeluaran tidak terduga lainnya yang sangat diperlukan dalam rangka penyelenggaraan kewenangan pemerintah, bersifat mendesak dan tidak dapat diprediksi sebelumnya.

\subsection{Pejabat Perbendaharaan Negara}

Ketentuan mengenai Pejabat Perbendaharaan Negara diatur dalam PMK No. 190/PMK.05/2012 tentang Tata Cara Pembayaran dalam Rangka Pelaksanaan Anggaran Pendapatan dan Belanja Negara. Menteri atau Pimpinan Lembaga selaku Pengguna Anggaran berwenang menunjuk Kuasa Pengguna Anggaran (KPA) dan menetapkan Pejabat Perbendaharaan Negara Lainnya (kewenangan ini dilimpahkan ke KPA), yaitu Pejabat Pembuat Komitmen (PPK) dan Pejabat Penandatangan Surat Perintah Membayar (PP-SPM).

KPA melekat pada jabatan kepala satker sehingga bila terjadi pergantian pejabat, pejabat yang baru langsung menjabat menjadi KPA. Jika terdapat kekosongan jabatan kepala satuan kerja, Pengguna Anggaran menunjuk KPA dari pejabat lain. KPA melaksanakan penggunaan anggaran berdasarkan DIPA satkernya. Penunjukkan KPA berakhir bila tidak terdapat alokasi anggaran untuk program yang sama di tahun anggaran berikutnya.

Untuk satu DIPA, KPA menetapkan satu PPK dan satu PPSPM (keduanya tidak dapat merangkap satu sama lain). Penetapan tersebut adalah dengan surat keputusan dan tidak terikat periode tahun anggaran. KPA menyampaikan surat keputusan tersebut kepada PPK, PPSPM disertai spesimen tanda tangan PPK, dan Kepala KPPN selaku Kuasa BUN disertai spesimen tanda tangan PPSPM dan stempel Satker. PPK melaksanakan kewenangan KPA untuk melakukan tindakan yang mengakibatkan pengeluaran anggaran belanja negara. PPSPM melaksakan kewenangan KPA untuk melakukan pengujian atas tagihan dan menerbitkan SPM.

Kepala Satker mengangkat Bendahara Pengeluaran yang ditetapkan dengan surat 
keputusan untuk melaksanakan tugas kebendaharaan dalam rangka pelaksanaan anggaran belanja dan tidak terikat periode tahun anggaran. Bendahara pengeluaran tidak dapat dirangkap oleh KPA, PPK, atau PPSPM. Satu bendahara pengeluaran ditetapkan untuk satu DIPA kecuali terdapat keterbatasan pegawai/ pejabat dan tidak perlu ditetapkan apabila dalam pengelolaan DIPA bersangkutan tidak memerlukan Bendahara Pengeluaran. Bendahara pengeluaran melaksanakan tugas kebendaharaan atas uang/ surat berharga yang berada dalam pengelolaannya.

Sesuai Peraturan Menteri Keuangan Nomor 190/PMK.05/2012, Menteri Keuangan selaku BUN mengangkat Kepala KPPN selaku Kuasa BUN untuk melaksanakan tugas kebendaharaan dalam rangka pelaksanaan anggaran dalam wilayah kerja yang telah ditetapkan. KPPN selaku Kuasa BUN melaksanakan pencairan dana berdasarkan perintah pembayaran yang diterbitkan oleh PPSPM atas nama KPA. Terkait dengan pelaksanaan pencairan dana, KPPN bertugas dan berwenang menguji dan meneliti kelengkapan SPM yang diterbitkan oleh PPSPM.

\subsection{Pengadaan Barang dan Jasa Pemerintah}

Pasal 1 ayat (1) Peraturan Presiden (Perpres) No. 70 Tahun 2012 menjelaskan bahwa Pengadaan Barang/ Jasa Pemerintah adalah kegiatan untuk memperoleh barang/ jasa oleh Kementerian/ Lembaga/ Satuan Kerja Perangkat Daerah/ Institusi yang prosesnya dimulai dari perencanaan kebutuhan sampai seluruh kegiatan untuk memperoleh barang/ jasa diselesaikan. Pengadaan barang/ jasa pemerintah dalam hal ini meliputi pengadaan atas barang, pekerjaan konstruksi, jasa konsultansi, dan jasa lainnya yang dilakukan oleh pejabat/ tim pengadaan bersertifikat dengan prinsip efisien, efektif, transparan, terbuka, bersaing, adil/ tidak diskriminatif, dan akuntabel.

Sebagaimana diatur oleh Perpres No. 54 Tahun 2010 tentang Pengadaan Barang/Jasa Pemerintah jo Perpres No. 70 Tahun 2012 (perubahan kedua), organisasi pengadaan meliputi PA/KPA, PPK, ULP/ Pejabat Pengadaan, dan Panitia/ Pejabat Penerima Hasil Pekerjaan. Perpres No. 70 Tahun 2012 menegaskan bahwa pengangkatan dan pemberhentian pejabat dalam organisasi pengadaan tidak terikat tahun anggaran.

\subsection{Mekanisme Pencairan Dana APBN}

Mekanisme Pencairan Dana APBN diatur dalam PMK No. 190/PMK.05/2012 tentang Tata Cara Pembayaran Dalam Rangka Pelaksanaan Anggaran Pendapatan dan Belanja Negara. Kegiatan Pencairan Dana APBN erat kaitannya dengan Surat Permintaan Pembayaran (SPP), Surat Perintah Membayar (SPM), dan Surat Perintah Pencairan Dana (SP2D) yang masing-masing didefinisikan sebagai berikut (Pasal 1, PMK No. 190/PMK.05/2012):

1. SPP adalah dokumen yang diterbitkan oleh PPK yang berisi permintaan pembayaran tagihan kepada negara;

2. SPM adalah dokumen yang diterbitkan oleh PPSPM untuk mencairkan dana yang bersumber dari DIPA;

3. SP2D adalah surat perintah yang diterbitkan oleh KPPN selaku Kuasa BUN untuk pelaksanaan pengeluaran atas beban APBN berdasarkan SPM.

SPP dibuat dan ditandatangani oleh PPK dilampiri bukti hak tagih yang akan dibebankan kepada negara dalam pelaksanaan kegiatan. PP-SPM kemudian menguji kebenaran SPP beserta dokumen pendukungnya. Jika hasil pengujian menunjukkan bahwa SPP memenuhi persyaratan untuk dibayarkan, PP-SPM menerbitkan SPM dengan membebankan tagihan pada mata anggaran yang telah disediakan dan melaporkan pelaksanaan pengujian dan perintah pembayaran tersebut kepada KPA dilampiri pernyataan kebenaran perhitungan dan tagihan dan/atau data perjanjian. KPA kemudian menyampaikan SPM beserta dokumen pendukungnya kepada Kuasa BUN, yaitu KPPN.

Dalam pencairan dana atas SPM yang diajukan oleh KPA, Kuasa BUN menerbitkan SP2D setelah melakukan pengujian terhadap SPM dengan meneliti kelengkapan dokumen pendukung SPM, menguji kebenaran perhitungan tagihan atas beban APBN yang tercantum dalam SPM, menguji kesesuaian SPM dengan DIPA yang menjadi dasar pembayaran, dan menguji ketersediaan jumlah dana dalam DIPA. Yang dimaksud dengan jumlah dana dalam DIPA tersebut adalah jumlah pagu dana dikurangi dengan jumlah dana yang telah direalisasikan, jumlah dana yang telah dibuatkan perjanjian untuk aktivitas di luar pencairan dana, dan uang persediaan yang belum dipertanggungjawabkan oleh Bendahara Pengeluaran. Setelah pengujian dilakukan dan SPM telah memenuhi persyaratan pengujian, Kuasa BUN menerbitkan SP2D untuk memindahbukukan dari rekening pengeluaran ke rekening yang dituju dalam SPM. Jika SPM berdasarkan pengujian dinyatakan tidak memenuhi persyaratan, Kuasa BUN berwenang menolak menerbitkan SP2D.

\subsection{Penyerapan Dana APBN}

Penyerapan merupakan realisasi atau pencairan anggaran. ${ }^{8}$ Dengan demikian, penyerapan dana APBN dapat diartikan sebagai proses direalisasikannya kegiatan- kegiatan yang dimuat dalam DIPA Satker dan dana untuk membiayai kegiatan- kegiatan tersebut dibayarkan kepada yang berhak menerimanya. Proses pembayaran tersebut mengakibatkan terjadinya pengeluaran negara yang umumnya ditandai dengan diterbitkannya SP2D oleh

8 Abdul Halim, Manajemen Keuangan Sektor Publik: Problematika Penerimaan dan Pengeluaran Pemerintah (Anggaran Pendapatan dan Belanja Negara/Daerah). (Jakarta: Salemba Empat, 2014), hlm. 84 
KPPN yang mengesahkan berpindahnya sejumlah uang dari Rekening Kas Umum Negara (R-KUN) ke rekening pihak yang berhak menerimanya. Penyerapan APBN atau pencairan dana tersebut terjadi sepanjang tahun dimana DIPA berlaku.

Proses pencairan dana dikatakan lambat apabila pencairan dana lebih lambat dari perencanaan dalam DIPA, dan dikatakan cepat apabila lebih cepat dari perencanaan dalam DIPA. ${ }^{9}$ Rencana pencairan dana dalam DIPA tersebut terdapat pada Halaman III. APBN berlaku untuk setahun dimulai dari awal tahun anggaran berkenaan. Dengan demikian, pelaksanaan APBN yang baik dan optimal seharusnya ditandai dengan terserapnya dana secara relatif merata sepanjang tahun. Hal ini sejalan dengan penjelasan pemerintah dalam Laporan Keuangan Pemerintah Pusat Tahun 2013 (Audited) bahwa peningkatan belanja pemerintah dari tahun ke tahun memiliki implikasi terhadap makro ekonomi sektor riil yang mempengaruhi konsumsi, investasi, dan berdampak pada pertumbuhan ekonomi nasional dan kesejahteraan masyarakat. Peningkatan belanja pemerintah tersebut idealnya diikuti dengan pola penyerapan dana yang responsif terkait peran APBN sebagai stimulus ekonomi ${ }^{10}$.

\subsection{Hasil Penelitian Sebelumnya}

Telah terdapat penelitian- penelitian sebelumnya yang membahas mengenai topik yang berkaitan dengan topik penelitian ini, yaitu faktor- faktor yang menjadi penyebab menumpuknya atau terkonsentrasinya pencairan dana APBN pada akhir tahun anggaran. Penelitian ini tidak terlepas dari penggunaan penelitian- penelitian tersebut sebagai bahan pertimbangan penulisan dan pengolahan data (penentuan objek, penentuan sampel, perolehan data, dan metode pengolahan data) sehingga dapat memperkaya penelitian ini dan hasil dari penelitian ini dapat diperbandingkan dengan penelitianpenelitian tersebut. Hasil dari penelitian- penelitian sebelumnya dapat dijelaskan sebagai berikut:

1. Iwan Dwi Kuswoyo (2011), dengan tesis berjudul "Analisis atas Faktor- faktor yang Menyebabkan Terkonsentrasinya Penyerapan Anggaran Belanja di Akhir Tahun Anggaran: Studi Kasus pada Satker Wilayah KPPN Kediri", dengan metode analisis faktor, hasil penelitiannya menunjukkan bahwa terdapat empat faktor utama yang menyebabkan terkonsentrasinya penyerapan anggaran belanja di akhir tahun anggaran, yaitu

9 Mashudi Adi Nugroho, Analisis Faktor-Faktor yang Menyebabkan Penumpukan Pencairan Dana APBN di Akhir Tahun (Studi Kasus di KPPN Malang), Skripsi, tidak dipublikasikan, (Malang: Fakultas Ekonomi dan Bisnis, Universitas Brawijaya, 2013), hlm. 38.

10 Kementerian Keuangan, Laporan Keuangan Pemerintah Pusat Tahun 2013-Audited, hlm. 39. faktor perencanaan anggaran, faktor pelaksanaan anggaran, faktor pengadaan barang/ jasa, dan faktor internal Satker.

2. Retno Miliasih (2012) dengan tesis berjudul "Analisis Keterlambatan Penyerapan Anggaran Belanja Satuan Kerja Kementerian Negara/ Lembaga TA 2010 di Wilayah Pembayaran KPPN Pekanbaru". Dengan metode analisis menggunakan tabel analisis cross tabulation menyimpulkan bahwa $75,25 \%$ Satker yang diteliti mengalami keterlambatan penyerapan anggaran belanja dengan penyebab utama terletak pada permasalahan internal Satker.

3. Hendris Herriyanto (2012) dengan tesis berjudul "Faktor-faktor yang Mempengaruhi Keterlambatan Penyerapan Anggaran Belanja pada Satuan Kerja Kementerian/ Lembaga di Wilayah Jakarta: Studi Kasus pada Satker Wilayah KPPN Jakarta I dan KPPN Jakarta IV". Dengan analisis faktor, penulis menemukan lima faktor yang menyebabkan keterlambatan penyerapan anggaran belanja pada Satker di Wilayah Jakarta, yaitu faktor perencanaan, faktor administrasi, faktor sumber daya manusia, faktor dokumen pengadaan, dan faktor penggantian uang persediaan. 30 (tiga puluh) variabel dan pertanyaan kuesioner dalam penelitian ini digunakan kembali oleh penulis untuk meneliti objek dan tahun penelitian yang berbeda dengan pertimbangan mengurangi kemungkinan kegagalan instrumen penelitian, yaitu kuesioner, dalam pengujian validitas dan reliabilitas.

4. Prasetyo Adi Priatno (2013) dengan skripsi berjudul "Analisis Faktor-faktor yang Mempengaruhi Penyerapan Anggaran pada Satuan Kerja Lingkup Pembayaran KPPN Blitar" dengan menggunakan metode analisis faktor dan regresi logistik, menemukan tiga faktor yang mempengaruhi penyerapan anggaran Satker, yaitu faktor administrasi dan SDM (tidak signifikan), faktor perencanaan (signifikan), dan faktor pengadaan barang dan jasa (signifikan).

5. Mashudi Adi Nugroho (2013) dengan skripsi berjudul "Analisis Faktor-faktor yang Menyebabkan Penumpukan Pencairan Dana APBN di Akhir Tahun Anggaran: Studi Kasus pada Satker Wilayah KPPN Malang". Penelitian tersebut menggunakan metode analisis faktor, dan menunjukkan hasil bahwa ditemukan enam faktor yang menyebabkan terkonsentrasinya penyerapan anggaran belanja di akhir tahun anggaran, yaitu faktor perencanaan, faktor peraturan, faktor sumber daya manusia, faktor teknis, faktor kendala koordinasi, dan faktor pengadaan barang/ jasa. 


\section{METODOLOGI PENELITIAN}

\subsection{Pendekatan dan Ruang Lingkup Penelitian}

Penulis menggunakan pendekatan kuantitatif dalam penelitian ini. Arikunto menjelaskan bahwa penelitian kuantitatif memiliki sifat umum antara lain kejelasan unsur (tujuan, subjek, dan sumber data), dapat menggunakan sampel, kejelasan desain, dan analisis data dilakukan setelah semua data terkumpul, serta pertimbangan lain peneliti yaitu ketersediaan waktu, dana, dan minat peneliti. Penelitian ini bersifat deskriptif-eksploratif. ${ }^{11}$ Penelitian eksploratif digunakan untuk mengumpulkan data awal tentang sesuatu, dan penelitian deskriptif digunakan untuk mengkaji sesuatu seperti apa adanya (variabel tunggal) atau pola hubungan antara dua variabel atau lebih. ${ }^{12}$

Objek penelitian ini adalah Satker lingkup KPPN Jakarta V. Penelitian ini dilakukan untuk mengetahui faktor-faktor yang menjadi penyebab penumpukan pencairan dana APBN pada akhir tahun anggaran pada Satker lingkup KPPN Jakarta V.

\subsection{Data Populasi dan Sampel}

Data yang digunakan dalam penelitian ini adalah data primer dan data sekunder. Penulis memperoleh data primer dengan menyebarkan kuesioner kepada narasumber pelaksana anggaran Satker, yaitu KPA atau PPK, sehingga didapatkan jawaban yang relevan dengan permasalahan penelitian. Kuesioner terdiri atas pertanyaan terbuka dan pertanyaan tertutup. Penulis memperoleh data sekunder dengan mengumpulkan data dari dokumen yang berkaitan dengan penelitian.

Dalam penelitian ini, yang dimaksud dengan populasi adalah pejabat perbendaharaan tertentu, yaitu Kuasa Pengguna Anggaran (KPA) atau Pejabat Pembuat Komitmen (PPK), seluruh Satker lingkup KPPN Jakarta $\mathrm{V}$ yang berkaitan dengan penyerapan dana APBN. Jumlah sampel yang dianjurkan dalam analisis faktor adalah antara 50 sampai $100 . .^{13}$ Salah satu metode penentuan sampel adalah sampling kuota yang didefinisikan oleh Siregar sebagai metode menetapkan sampel dengan menentukan kuota terlebih dahulu pada setiap kelompok dan penelitian belum dianggap selesai sebelum kuota tersebut

11 Suharsimi Arikunto, Prosedur Penelitian Suatu Pendekatan Praktik, (Jakarta: Rineka Cipta, 2006), hlm. 13.

12 Prasetya Irawan, Penelitian Kualitatif dan Kuantitatif untuk Ilmu-Ilmu Sosial, (Jakarta: DIA FISIP UI, 2007), hlm. 101.

13 Singgih Santoso, Statistik Multivariat: Konsep dan Aplikasi dengan SPSS, (Jakarta: Elex Media Komputindo, 2010), hlm. 58. terpenuhi.14 Dengan dasar tersebut, penulis menentukan sampel dalam penelitian ini sebanyak 100 responden yang diambil dengan metode sampling kuota.

\subsection{Variabel Penelitian}

Penelitian ini menggunakan 30 variabel penelitian sebagaimana yang telah digunakan pada penelitian Herriyanto (2012) dengan objek penelitian yang berbeda. Variabel-variabel tersebut, yaitu:

1. Anggaran kegiatan diblokir (Q1);

2. Salah dalam penentuan akun (Q2);

3. Masa penyusunan dan penelaahan anggaran yang terlalu pendek (Q3);

4. SK Penunjukan/ Penggantian Pejabat Perbendaharaan terlambat ditetapkan (Q4);

5. SDM (sumber daya manusia) pelaksana pengadaan kurang kompeten (Q5);

6. Rangkap tugas dalam jabatan panitia pengadaan (Q6);

7. Ketakutan Pejabat melaksanakan pengadaan akibat pemberitaan penangkapan dengan tuduhan korupsi (Q7);

8. Keengganan untuk menjadi pejabat pengadaan karena tidak seimbangnya risiko pekerjaan dengan imbalan yang diterima (Q8);

9. Keterbatasan pejabat/ pelaksana pengadaan yang bersertifikat (Q9);

10. SK Panitia Lelang terlambat ditetapkan (Q10);

11. Terlambatnya penyusunan jadwal pelaksanaan lelang (Q11);

12. Jadwal pelaksanaan lelang yang disusun tidak realistis atau tidak sesuai dengan kebutuhan (Q12);

13. Kesulitan menentukan Harga Perkiraan Sendiri (HPS) dan HPS tidak ditentukan melalui keahlian dan survey pasar (Q13);

14. Terlambat dalam pengesahan dokumen lelang (Q14);

15. Proses lelang masih dalam masa sanggah dan masih menunggu proses hukum (Q15);

16. Panitia/ Pejabat Pengadaan dan/ atau Unit Layanan Pengadaan (ULP) belum dibentuk (Q16);

17. Kontrak belum ditandatangani karena terdapat berbagai permasalahan seperti masih menunggu persetujuan lender (PPHLN) (Q17);

18. Adanya adendum kontrak (Q18);

19. Pembentukan panitia pembebasan tanah terlambat ditetapkan (Q19);

20. Terdapat permasalahan terkait pembebasan tanah (Q20);

21. Terdapat permasalahan terkait pengadaan peralatan/ mesin (Q21);

14 Syofian Siregar, Metode Penelitian Kuantitatif: Dilengkapi Perbandingan Perhitungan Manual \& SPSS, (Jakarta: Kencana Prenada Media Group, 2013), hlm. 33-34. 
22. SK Penunjukan panitia pelaksana kegiatan swakelola belum ditetapkan (Q22);

23. Kurangnya pemahaman terhadap peraturan mengenai mekanisme pembayaran (Q23);

24. DIPA perlu direvisi karena tidak sesuai dengan kebutuhan (Q24);

25. Kegiatan sudah dilaksanakan dengan UP tapi belum diganti melalui GUP (Q25);

26. Adanya tambahan pagu karena ABT, kelebihan realisasi PNBP, tambahan/ luncuran PHLN/ PHDN, dan/ atau penerimaan hibah (Q26);

27. Pelaksanaan kegiatan/ proyek tidak melihat rencana/ jadwal penarikan dana yang tercantum dalam halaman 3 DIPA (Q27);

28. Pejabat/ pegawai pengelola keuangan sering mengalami mutasi (Q28);

29. Tidak adanya mekanisme reward dan punisment dalam pengelolaan anggaran pada Satker (Q29);

30. Terdapat kultur/ kebiasaan seperti menunda pekerjaan, tidak disiplin, mengerjakan pekerjaan di menit terakhir (Q30).

\subsection{Metode Analisis Data}

Penelitian ini menggunakan metode analisis data berupa analisis faktor. Pengujian atas kualitas instrumen, yaitu uji validitas dan uji reliabilitas harus dilakukan sebelum analisis faktor.

Pengujian validitas digunakan untuk mengukur valid tidaknya suatu kuesioner dimana kuesioner yang valid memiliki pertanyaan yang mampu mengungkapkan sesuatu yang akan diukur oleh kuesioner tersebut. ${ }^{15}$ Penulis melakukan pengujian ini dengan membandingkan $r$ hitung dan $r$ tabel. Nilai $r$ hitung dihasilkan dari nilai Corrected Item Total Correlation dengan bantuan program SPSS. Nilai ini kemudian dibandingkan dengan $r$ tabel dengan $D f=n-2$ dan nilai signifikansi $\propto=5 \%$. Instrumen dikatakan valid jika $r$ hitung lebih besar dari $r$ tabel.

Pengujian reliabilitas dimaksudkan untuk mengetahui apakah jawaban seseorang terhadap pernyataan adalah konsisten atau stabil dari waktu ke waktu. ${ }^{16}$ Penulis melakukan pengujian ini dengan menggunakan Cronbach Alpha dimana koefisien alpha dimiliki oleh setiap pertanyaan. Instrumen dikatakan andal (reliable) jika Cronbach Alpha bernilai $>0,6$.

Analisis faktor adalah teknik mencari faktor yang mampu menjelaskan hubungan berbagai indikator independen yang diobservasi. ${ }^{17}$ Penelitian ini

15 Imam Ghozali, Aplikasi Analisis Multivariate Dengan Program IBM SPSS 22 Update PLS Regresi. Edisi ke-7, (Semarang: Badan Penerbit Universitas Diponegoro, 2013), hlm. 52.

16 Ibid., hlm.47.

17 Agus Widarjono, Analisis Multivariat Terapan: Dengan Program SPSS, AMOS, dan SMARTPLS, Edisi menggunakan Exploratory Factor Analysis, dimana sejumlah indikator dicari untuk membentuk faktor umum tanpa ada landasan teori sebelumnya atau merupakan sebuah metode untuk membangun teori.

Langkah-langkah analisis faktor yang akan digunakan dalam penelitian ini adalah sebagai berikut:

a. Menghitung korelasi indikator

Menganalisis apakah data yang ada cukup memenuhi syarat dalam analisis factor, adalah keputusan pertama yang harus dilakukan dalam analisis faktor. ${ }^{18}$ Dalam penelitian ini, penulis menggunakan metode Uji Bartlett (Bartlett's test of sphericity), Kaiser-Meyer Olkin (KMO), dan Measure Sampling Adequacy (MSA) untuk menghitung korelasi indikator.

Uji Bartlett merupakan uji statistik untuk signifikansi menyeluruh semua korelasi di dalam matriks korelasi dan dilakukan dengan menguji apakah data yang diobservasi merupakan sampel dari distribusi populasi normal multivariat dengan semua koefisien korelasi bernilai nol. Metode KMO mengukur kecukupan sampling secara menyeluruh dan untuk setiap indikator dengan mengukur homogenitas indikator. Untuk analisis faktor, KMO harus bernilai di atas 0,5 , signifikansi pada uji Bartlett di bawah 5\%, dan MSA di bawah 0,5.

\section{b. Ekstraksi faktor}

Langkah ke-2 dalam analisis faktor adalah ekstraksi faktor, yang merupakan metode mereduksi data dari berbagai indikator untuk mendapat faktor yang lebih sedikit dan mampu menjelaskan korelasi antara indikator-indikator yang diobservasi. Pada tahap ini, item-item pertanyaan didistribusikan ke faktor-faktor yang telah dibentuk. ${ }^{19}$

Dalam penelitian ini, penulis menggunakan metode Principal Component Analysis sebagai metode ekstraksi faktor. Metode ini membentuk kombinasi linier dari indikator yang diobservasi dimana komponen utama pertama adalah kombinasi yang menjelaskan varian dengan jumlah terbesar dari sampel, komponen utama kedua menjelaskan varian terbesar kedua dan tidak berhubungan dengan komponen utama pertama, dan komponen utama berikutnya menjelaskan porsi lebih kecil dari varian sampel total dan tidak berhubungan dengan yang lainnya.

\section{c. Rotasi faktor}

Langkah berikutnya setelah melakukan ekstraksi faktor adalah rotasi faktor. Rotasi faktor diperlukan apabila ekstraksi faktor belum menghasilkan

ke-3, (Yogyakarta: UPP STIM YKPN, 2015), hlm. 189.

18 Ibid., hlm. 194

19 Ibid., hlm. 196 
komponen faktor utama yang jelas dan memiliki tujuan untuk memperoleh struktur faktor yang lebih sederhana sehingga mudah diinterpretasikan. ${ }^{20}$ Penelitian ini menggunakan Varimax Method sebagai metode rotasi faktor orthogonal untuk meminimalkan jumlah indikator dengan factor loading tinggi pada setiap faktor.

\section{d. Penamaan faktor}

Setelah rotasi faktor mereduksi indikatorindikator menjadi beberapa faktor, setiap faktor yang dibentuk diberi nama yang idealnya merupakan nama yang mewakili semua variabel yang membentuk faktor tersebut. Namun, menurut Kuswoyo, apabila tidak dimungkinkan untuk memberi nama faktor yang dapat mewakili semua variabel pembentuk faktor tersebut, penamaan faktor dapat melihat variabel dengan factor loading tertinggi. ${ }^{21}$

\section{HASIL PENELITIAN}

\subsection{Pengumpulan Data}

Penulis mengumpulkan data primer dengan menyebarkan kuesioner kepada responden, yaitu Kuasa Pengguna Anggaran (KPA) atau Pejabat Pembuat Komitmen (PPK) pada Satker lingkup kerja KPPN Jakarta V. Penentuan KPA atau PPK sebagai responden menimbang bahwa pejabat bersangkutan seharusnya lebih memahami permasalahan yang terjadi selama ini, khususnya berkaitan dengan perencanaan dan pelaksanaan anggaran dari pada jabatan perbendaharaan yang lain, sehingga jawaban responden dapat benar- benar mencerminkan keadaan sebenarnya dalam Satker tersebut. Selain itu, penulis memilih salah satu pejabat perbendaharaan, yaitu KPA atau PPK guna mendapat satu responden yang menjadi representasi Satker bersangkutan dan menghindari data yang bias apabila diisi lebih dari satu pegawai dari Satker yang sama.

Pendistribusian dan penerimaan jawaban kuesioner dimulai dari awal Agustus 2015 sampai dengan awal September 2015. Kuesioner yang digunakan dalam penelitian ini terdiri atas empat bagian, yaitu bagian pertama (A) berisi pertanyaan tentang identitas responden, bagian kedua (B) berisi pertanyaan tertutup berupa 30 pertanyaan berdasarkan persepsi responden, bagian ketiga $(\mathrm{C})$ berisi pertanyaan terbuka, yaitu faktor penyebab utama menumpuknya pencairan dana APBN pada

20 Ibid., hlm.197

21 Iwan Dwi Kuswoyo, Analisis atas Faktor-Faktor yang Menyebabkan Terkonsentrasinya Penyerapan Anggaran Belanja di Akhir Tahun Anggaran (Studi pada Satuan Kerja di Wilayah KPPN Kediri), Tesis, tidak dipublikasikan, (Yogyakarta: Fakultas Ekonomika dan Bisnis, Universitas Gadjah Mada, 2011), hlm. 62. akhir tahun anggaran untuk Satker bersangkutan, dan bagian keempat (D) berisi pertanyaan tentang profil Satker.

Penulis mendistribusikan kuesioner kepada responden sebanyak 300 eksemplar dan menerima jumlah kuesioner yang kembali sebanyak 115 eksemplar atau 38,33\% dari jumlah eksemplar yang didistribusikan, dan dari jumlah tersebut sebanyak 113 telah mengisi pertanyaan inti dengan lengkap. Dengan demikian, jumlah yang kembali tersebut telah memenuhi jumlah sampel yang dianjurkan dalam analisis faktor, yaitu 50 sampai 100 sampel.

\subsection{Uji Kualitas Instrumen}

\subsubsection{Uji Validitas}

Pengujian validitas digunakan untuk mengukur valid tidaknya suatu kuesioner dimana kuesioner yang valid memiliki pertanyaan yang mampu mengungkapkan sesuatu yang akan diukur oleh kuesioner tersebut. ${ }^{22}$ Pengujian ini dilakukan dengan membandingkan nilai $r$ hitung dan $r$ tabel. Nilai $r$ hitung dihasilkan dari nilai Corrected Item Total Correlation yang didapatkan dengan bantuan program SPSS versi 22.0. Nilai ini kemudian dibandingkan dengan $r$ tabel dengan $D f=n-2$ dan nilai signifikansi $95 \% \quad(\propto=5 \%)$. Penelitian ini menggunakan 113 data responden sehingga didapatkan nilai DF sebesar 111 (113-2). Dengan $D f$ sebesar 111 dan nilai signifikansi 95\% ( $\propto=5 \%)$ didapatkan nilai $r$ tabel sebesar 0,1848 (dari $r$ tabel uji 2 arah). Suatu instrumen dikatakan valid jika nilai $r$ hitung lebih besar dari nilai $r$ tabel.

Hasil uji validitas menunjukkan bahwa dari 30 pertanyaan, 1 pertanyaan (Q29: Tidak adanya mekanisme reward dan punishment dalam pengelolaan anggaran pada Satker) dinyatakan tidak valid karena memiliki $r$ hitung $(0,1214)$ yang lebih rendah dari $r$ tabel $(0,1848)$. Sebanyak 29 pertanyaan lainnya dinyatakan valid karena masingmasing memiliki $r$ hitung yang lebih besar $r$ tabel sehingga dapat digunakan untuk dianalisis lebih lanjut.

\subsubsection{Uji Reliabilitas}

Setelah melakukan uji validitas dan mengeluarkan pertanyaan yang tidak valid, penulis melakukan uji reliabilitas. Pengujian reliabilitas dimaksudkan untuk mengetahui apakah jawaban seseorang terhadap pernyataan adalah konsisten atau stabil dari waktu ke waktu. ${ }^{23}$ Penulis melakukan pengujian ini dengan menggunakan Cronbach Alpha dimana koefisien alpha dimiliki oleh setiap pertanyaan. Instrumen berupa kuesioner dikatakan andal (reliable) jika Cronbach Alpha bernilai lebih besar dari (>) 0,6. Hasil uji reliabilitas menunjukkan bahwa nilai Cronbach Alpha adalah sebesar 0,900

\footnotetext{
22 Imam Ghozali, Op.Cit., hlm. 52.

23 Ibid., hlm. 47.
} 
$(>0,6)$. Hal ini berarti bahwa instrumen yang digunakan dalam penelitian ini dapat dikatakan andal.

\subsection{Analisis Faktor}

\subsubsection{Uji Korelasi Antar Variable}

Penulis melakukan uji korelasi antar variabel dengan metode Uji Bartlett (Bartlett's test of sphericity) dan Kaiser-Meyer Olkin (KMO). Uji Bartlett merupakan uji statistik untuk signifikansi menyeluruh semua korelasi di dalam matriks korelasi dan dilakukan dengan menguji apakah data yang diobservasi merupakan sampel dari distribusi populasi normal multivariat dengan semua koefisien korelasi bernilai nol. Metode KMO mengukur kecukupan sampling secara menyeluruh dan untuk setiap indikator dengan mengukur homogenitas indikator. Untuk analisis faktor, KMO harus bernilai di atas $0,5 .{ }^{24}$

Hasil pengujian terhadap 29 pertanyaan yang valid menunjukkan nilai Kaiser-Meyer Olkin (KMO) sebesar 0,729 $(>0,5)$ dan Bartlett's test of sphericity sebesar $0,000 \quad(<0,05)$, sehingga layak untuk dilakukan analisis faktor selanjutnya. Penulis melakukan uji korelasi antarvariabel lainnya dengan melihat nilai measure sampling adequacy (MSA). MSA untuk seluruh 29 pertanyaan memiliki nilai masingmasing lebih besar dari 0,5 sehingga lolos uji korelasi.

\subsubsection{Ekstraksi Faktor}

Langkah kedua dalam analisis faktor adalah mereduksi data dengan ekstraksi faktor untuk mendapat faktor yang lebih sedikit dan mampu menjelaskan korelasi antara indikator-indikator yang diobservasi. ${ }^{25}$ Penulis melakukan ekstraksi faktor dengan menggunakan metode Principal Component Analysis dan kriteria eigenvalue $>1$.

Dari hasil ekstraksi faktor terbentuk 8 (delapan) faktor dengan eigenvalue $>1$ dan persentase varian kumulatif $68,324 \%$ dengan setiap faktor dijelaskan sebagai berikut:

a. Faktor pertama memiliki eigenvalue sebesar 8,002 yang mampu menjelaskan variasi seluruh item sebesar 27,592\%;

b. Faktor kedua memiliki eigenvalue sebesar 2,811 yang mampu menjelaskan variasi seluruh item sebesar 9,693\%;

c. Faktor ketiga memiliki eigenvalue sebesar 2,126 yang mampu menjelaskan variasi seluruh item sebesar 7,330\%;

24 Agus Widarjono, Analisis Multivariat Terapan: Dengan Program SPSS, AMOS, dan SMARTPLS, Edisi ke-3, (Yogyakarta: UPP STIM YKPN, 2015), hlm.194.

25 Ibid., hlm. 196 d. Faktor keempat memiliki eigenvalue sebesar 1,834 yang mampu menjelaskan variasi seluruh item sebesar 6,325\%;

e. Faktor kelima memiliki eigenvalue sebesar 1,487 yang mampu menjelaskan variasi seluruh item sebesar 5,127\%;

f. Faktor keenam memiliki eigenvalue sebesar 1,347 yang mampu menjelaskan variasi seluruh item sebesar 4,643\%;

g. Faktor ketujuh memiliki eigenvalue sebesar 1,180 yang mampu menjelaskan variasi seluruh item sebesar 4,069\%.

h. Faktor kedelapan memiliki eigenvalue sebesar 1,028 yang mampu menjelaskan variasi seluruh item sebesar 3,544\%.

Penulis mendistribusikan variabel- variabel ke setiap faktor berdasarkan nilai factor loading terbesar (nilai mutlak) item pada setiap komponen dengan bantuan SPSS 22.0. Terdapat banyak item pertanyaan yang masuk pada faktor (component) 1 , terdapat item pertanyaan yang tidak jelas masuk ke faktor yang mana (Q4), dan terdapat faktor yang tidak mendapat distribusi item pertanyaan. Guna mendistribusikannya secara lebih jelas dan merata diperlukan tahap berikutnya dalam analisis faktor, yaitu rotasi faktor.

\subsubsection{Rotasi Faktor}

Apabila ekstraksi faktor belum menghasilkan komponen faktor utama yang jelas dan guna memperoleh struktur faktor yang lebih sederhana agar mudah diinterpretasikan diperlukan rotasi faktor. ${ }^{26}$ Ekstraksi faktor yang telah dilakukan menghasilkan distribusi item pertanyaan ke faktorfaktor secara tidak jelas dan tidak merata sehingga diperlukan rotasi faktor untuk meratakan distribusi tersebut.

Penulis menggunakan Varimax Method sebagai metode rotasi faktor orthogonal untuk meminimalkan jumlah indikator dengan factor loading tinggi pada tiap faktor. Tabel 1 menunjukkan distribusi item pertanyaan (variabel) ke faktor-faktor yang telah terbentuk setelah rotasi faktor. 
Tabel 1. Distribusi ke Faktor Setelah Dirotasi

\begin{tabular}{|c|l|}
\hline Faktor & \multicolumn{1}{|c|}{ Item dan factor loading } \\
\hline 1 & $\begin{array}{l}\text { Q27 }(0,733), \mathrm{Q} 25(0,714), \mathrm{Q} 23(0,605), \mathrm{Q} 30 \\
(0,567), \mathrm{Q} 22(0,514), \mathrm{Q} 15(0,494)\end{array}$ \\
\hline 2 & $\mathrm{Q} 20(0,804), \mathrm{Q} 19(0,749), \mathrm{Q} 17(0,673), \mathrm{Q} 18(0,466)$ \\
\hline 3 & $\mathrm{Q} 24(0,777), \mathrm{Q} 3(0,695), \mathrm{Q} 1(0,624), \mathrm{Q} 2(0,457)$ \\
\hline 4 & $\mathrm{Q} 16(0,777), \mathrm{Q} 4(0,734), \mathrm{Q} 10(0,549)$ \\
\hline 5 & $\mathrm{Q} 14(0,846), \mathrm{Q} 12(0,718), \mathrm{Q} 13(0,523), \mathrm{Q} 21(0,446)$ \\
\hline 6 & $\mathrm{Q} 9(0,726), \mathrm{Q} 8(0,675), \mathrm{Q} 7(0,621), \mathrm{Q} 6(0,618)$ \\
\hline 7 & $\mathrm{Q} 11(0,800), \mathrm{Q} 5(0,614), \mathrm{Q} 26(-0,484)$ \\
\hline 8 & $\mathrm{Q} 28(0,814)$ \\
\hline
\end{tabular}

Sumber: data primer, diolah dengan SPSS 22.0

\subsubsection{Penamaan Faktor yang Terbentuk}

Setelah mendistribusikan setiap item pertanyaan ke setiap faktor yang terbentuk, penulis memberi nama faktor-faktor tersebut. Penamaan setiap faktor idealnya berdasarkan karakteristik yang merepresentasikan seluruh item pertanyaan (variabel pembentuk faktor) yang ada pada faktor tersebut. Namun demikian, jika tidak dimungkinkan untuk memberi nama faktor yang dapat mewakili semua variabel pembentuk faktor tersebut, penamaan faktor dapat melihat variabel dengan factor loading tertinggi. ${ }^{27}$ Pemberian nama setiap faktor yang terbentuk dalam penelitian ini adalah sebagai berikut:

a. Faktor 1 : Faktor Administrasi Perbendaharaan;

b. Faktor 2 : Faktor Pelaksanaan Pengadaan;

c. Faktor 3 : Faktor Perencanaan;

d. Faktor 4 : Faktor Persyaratan Teknis Pendukung;

e. Faktor 5 : Faktor Jadwal Pengadaan;

f. Faktor 6 : Faktor Sumber Daya Manusia;

g. Faktor 7 : Faktor Kompetensi;

h. Faktor 8 : Faktor Mutasi Pejabat.

Analisis faktor membentuk faktor pertama yang diberi nama faktor administrasi perbendaharaan. Faktor tersebut merupakan faktor dengan eigenvalue tertinggi sebesar 8,022 dengan variansi yang dapat menjelaskan variasi seluruh item pertanyaan sebesar $27,592 \%$. Terdapat enam variabel yang membentuk faktor tersebut, yaitu:

a. Proses lelang masih dalam masa sanggah dan masih menunggu proses hukum (Q15) dengan factor loading sebesar 0,494;

b. SK penunjukan panitia pelaksanaan kegiatan swakelola belum ditetapkan (Q22) dengan factor loading sebesar 0,514;

c. Kurangnya pemahaman terhadap peraturan tentang mekanisme pembayaran (Q23) dengan factor loading sebesar 0,605;

27 Iwan Dwi Kuswoyo., Op.Cit., hlm. 62. d. Kegiatan sudah dilaksanakan dengan UP tapi belum diganti dengan GUP (Q25) dengan factor loading sebesar 0,714;

e. Pelaksanaan kegiatan/proyek tidak melihat rencana/ jadwal penarikan dana yang tercantum dalam halaman 3 DIPA (Q27) factor loading sebesar 0,733;

f. Terdapat kultur/ kebiasaan seperti menunda pekerjaan, tidak disiplin, mengerjakan pekerjaan di menit terakhir (Q30) dengan factor loading sebesar 0,567 .

Analisis faktor membentuk faktor kedua yang diberi nama faktor pelaksanaan pengadaan. Faktor tersebut merupakan faktor dengan eigenvalue sebesar 2,811 dengan variansi yang dapat menjelaskan variasi seluruh item pertanyaan sebesar 9,693\%. Terdapat empat variabel yang membentuk faktor tersebut, yaitu:

a. Kontrak belum ditandatangani karena terdapat berbagai permasalahan seperti masih menunggu persetujuan lender (PPHLN) (Q17) factor loading sebesar 0,673;

b. Adanya addendum kontrak (Q18) factor loading sebesar 0,466;

c. Pembentukan panitia pembebasan tanah terlambat ditetapkan (Q19) factor loading sebesar 0,749;

d. Terdapat permasalahan terkait pembebasan tanah (Q20) factor loading sebesar 0,804.

Analisis faktor membentuk faktor ketiga yang diberi nama faktor perencanaan. Faktor tersebut merupakan faktor dengan eigenvalue sebesar 2,126 dan variansi yang dapat menjelaskan variasi seluruh item pertanyaan sebesar 7,330\%. Terdapat empat variabel yang membentuk faktor tersebut, yaitu:

a. Anggaran kegiatan diblokir (Q1) factor loading sebesar 0,624;

b. Salah dalam penentuan akun (Q2) factor loading sebesar 0,457;

c. Masa penyusunan dan penelaahan anggaran yang terlalu pendek (Q3) factor loading sebesar 0,695;

d. DIPA perlu direvisi karena tidak sesuai dengan kebutuhan (Q24) factor loading sebesar 0,777.

Analisis faktor membentuk faktor keempat yang diberi nama faktor persyaratan teknis pendukung. Faktor tersebut merupakan faktor dengan eigenvalue sebesar 1,834 dengan variansi yang dapat menjelaskan variasi seluruh item pertanyaan sebesar $6,325 \%$. Terdapat tiga variabel yang membentuk faktor tersebut, yaitu:

a. SK Penunjukan/ Penggantian Pejabat Perbendaharaan terlambat ditetapkan (Q4) dengan factor loading sebesar 0,734;

b. SK Panitia Lelang terlambat ditetapkan (Q10) dengan factor loading sebesar 0,549;

c. Panitia/ Pejabat Pengadaan dan/ atau Unit Layanan Pengadaan (ULP) belum dibentuk (Q16) dengan factor loading sebesar 0,777. 
Analisis faktor membentuk faktor kelima yang diberi nama faktor jadwal pengadaan. Faktor tersebut merupakan faktor dengan eigenvalue sebesar 1,487 dengan variansi yang dapat menjelaskan variasi seluruh item pertanyaan sebesar 5,127\%. Terdapat empat variabel yang membentuk faktor tersebut, yaitu:

a. Jadwal pelaksanaan lelang yang disusun tidak realistis atau tidak sesuai kebutuhan (Q12) dengan factor loading sebesar 0,718;

b. Kesulitan menentukan Harga Perkiraan Sendiri (HPS) dan HPS tidak ditentukan melalui keahlian dan survey pasar (Q13) dengan factor loading sebesar 0,523.

c. Terlambat dalam pengesahan dokumen pengumuman lelang (Q14) dengan factor loading sebesar 0,846;

d. Terdapat permasalahan terkait pengadaan peralatan/ mesin (Q21) dengan factor loading sebesar 0,446

Analisis faktor membentuk faktor keenam yang diberi nama faktor sumber daya manusia. Faktor tersebut merupakan faktor dengan eigenvalue sebesar 1,347 dengan variansi yang dapat menjelaskan variasi seluruh item pertanyaan sebesar 4,643\%. Terdapat empat variabel yang membentuk faktor tersebut, yaitu:

a. Rangkap tugas dalam jabatan panitia pengadaan (Q6) dengan factor loading sebesar 0,618;

b. Ketakutan pejabat melaksanakan pengadaan akibat pemberitaan penangkapan dengan tuduhan korupsi (Q7) dengan factor loading sebesar 0,621;

c. Keengganan untuk menjadi pejabat pengadaan karena tidak seimbangnya risiko pekerjaan dengan imbalan yang diterima (Q8) dengan factor loading sebesar 0,675;

d. Keterbatasan pejabat/ pelaksana pengadaan yang bersertifikat (Q9) dengan factor loading sebesar 0,726 .

Analisis faktor membentuk faktor ketujuh yang diberi nama faktor kompetensi. Faktor tersebut merupakan faktor dengan eigenvalue sebesar 1,180 dengan variansi yang dapat menjelaskan variasi seluruh item pertanyaan sebesar 4,069\%. Terdapat tiga variabel yang membentuk faktor tersebut, yaitu:

a. SDM pelaksana pengadaan kurang kompeten (Q5) dengan factor loading sebesar 0,614;

b. Terlambatnya penyusunan jadwal pelaksanaan lelang (Q11) dengan factor loading sebesar 0,800;

c. Adanya tambahan pagu karena ABT, kelebihan realisasi PNBP, tambahan/ luncuran PHLN/PHDN, dan/ atau penerimaan hibah (Q26) dengan factor loading sebesar $-0,484$.

Analisis faktor membentuk faktor kedelapan yang diberi nama faktor mutasi pejabat. Faktor tersebut merupakan faktor dengan eigenvalue sebesar 1,028 dengan variansi yang dapat menjelaskan variasi seluruh item pertanyaan sebesar 3,544\%. Satusatunya variabel yang membentuk faktor ini adalah pejabat/pegawai pengelola keuangan sering mengalami mutasi (Q28) dengan factor loading sebesar 0,814

\subsection{Pembahasan Faktor}

\subsubsection{Faktor Administrasi Perbendaharaan}

Responden yang menyatakan setuju dan sangat setuju bahwa enam variabel pembentuk faktor administrasi perbendaharaan (Q15, Q22, Q23, Q25, Q27, dan Q30) merupakan masalah yang menyebabkan penumpukan pencairan dana APBN pada akhir tahun anggaran adalah rata-rata sebesar $32,45 \%$. Dua variabel pembentuk faktor administrasi perbendaharaan dengan persentase responden terbesar yang menyetujui keduanya sebagai permasalahan yang menyebabkan penumpukan pencairan dana APBN pada akhir tahun anggaran adalah pelaksanaan kegiatan/proyek tidak melihat rencana/jadwal penarikan dana yang tercantum dalam halaman 3 DIPA (Q27) dan terdapat kultur/kebiasaan seperti menunda pekerjaan, tidak disiplin, mengerjakan pekerjaan di menit terakhir (Q30).

Atas masalah yang pertama (Q27), solusi kebijakan yang dapat diambil adalah dengan selalu mempertimbangkan halaman 3 DIPA yang memuat rencana/jadwal penarikan dana yang umumnya teratur per bulannya dalam pelaksanaan kegiatan/proyek. Dalam hal ini, kepala unit atau atasan langsung pelaksana kegiatan/proyek dapat melakukan perbandingan atas rencana kebutuhan dana atas kegiatan dengan rencana penarikan yang terdapat pada halaman 3 DIPA. Atas masalah yang kedua (Q30), solusi kebijakan yang dapat diambil adalah dengan membentuk unit pengawas satker baik yang bersifat internal dan independen maupun dari unit vertikal di atasnya seperti unit wilayah dan kantor pusat. Selain itu, meningkatkan insentif kerja seperti pemberian reward dan punishment dapat berperan untuk mengatasi masalah tersebut.

\subsubsection{Faktor Pelaksanaan Pengadaan}

Responden yang menyatakan setuju dan sangat setuju bahwa empat variabel pembentuk faktor pelaksanaan pengadaan (Q17, Q18, Q19, dan Q20) merupakan masalah yang menyebabkan penumpukan pencairan dana APBN pada akhir tahun anggaran adalah rata-rata sebesar $37,17 \%$. Dua variabel pembentuk faktor pelaksanaan pengadaan dengan persentase responden terbesar yang menyetujui keduanya sebagai permasalahan yang menyebabkan penumpukan pencairan dana APBN pada akhir tahun anggaran adalah adanya adendum kontrak (Q18) dan adanya permasalahan terkait pembebasan tanah (Q20).

Guna mengatasi terjadinya adendum kontrak, satker harus lebih memperhatikan kebutuhan dalam membuat spesifikasi kerja yang akan disepakati 
dengan pihak ketiga, mengawasi pekerjaan yang pihak ketiga lakukan, dan melakukan komunikasi rutin atas perkembangan hasil kerja dengan pihak ketiga. Guna mengatasi permasalahan dalam pembebasan tanah, satker dapat melakukan penelitian pendahuluan atas harga tanah yang akan dibebaskan pada tahun berikutnya dan menyesuaiakannya dengan rencana anggaran yang disediakan untuk membebaskan tanah tersebut. Satker juga dapat melakukan negosiasi awal dengan pemilik tanah sebelum merencanakan kegiatan/ proyek yang membutuhkan pembebasan tanah bersangkutan. Negosiator yang andal juga dapat dipilih untuk lebih melancarkan negosiasi terutama dengan keterbatasan alokasi dana yang tersedia.

\subsubsection{Faktor Perencanaan}

Responden yang menyatakan setuju dan sangat setuju bahwa empat variabel pembentuk faktor perencanaan (Q1, Q2, Q3, dan Q24) merupakan masalah yang menyebabkan penumpukan pencairan dana APBN pada akhir tahun anggaran adalah ratarata sebesar 55,09\%. Tiga variabel pembentuk faktor perencanaan dengan persentase responden yang menyetujui ketiganya lebih dari $50 \%$ responden sebagai permasalahan yang menyebabkan penumpukan pencairan dana APBN pada akhir tahun anggaran adalah salah dalam penentuan akun (Q2), masa penyusunan dan penelaahan anggaran yang terlalu pendek (Q3), dan DIPA perlu direvisi karena tidak sesuai kebutuhan (Q4).

Guna mengatasi terjadinya kesalahan dalam menentukan akun, Satker harus teliti dalam memilih akun yang sesuai dengan kegiatan yang akan direncanakan pada tahun anggaran bersangkutan. Akun yang akan dipilih umumnya telah disertai penjelasan pada Bagan Akun Standar (BAS) sehingga memudahkan pencocokan dengan kegiatan tersebut. Masa penyusunan dan penelaahan anggaran yang terlalu pendek perlu diatasi dengan kebijakan evaluasi penyediaan waktu yang memadai dalam menyusun dan menelaah anggaran. Selain itu, masa penyusunan dan penelaahan anggaran yang terlalu pendek dapat diatasi dengan melakukan perencanaan kebutuhan kegiatan periode berikutnya secara lebih awal dan menyiapkan data pendukung yang memadai. Revisi DIPA dapat diminimalkan dengan cara merencanakan anggaran secara lebih matang sesuai kebutuhan. Namun, untuk membantu pelaksanaan kegiatan yang sulit direncanakan dan memerlukan revisi DIPA, perlu kebijakan yang memudahkan revisi sehingga tidak memakan waktu lama.

\subsubsection{Faktor Persyaratan Teknis Pendukung}

Responden yang menyatakan setuju dan sangat setuju bahwa tiga variabel pembentuk faktor teknis pendukung (Q4, Q10, dan Q16) merupakan masalah yang menyebabkan penumpukan pencairan dana APBN pada akhir tahun anggaran adalah rata-rata sebesar 19,17\%. Persentase responden yang menyetujui ketiga variabel tersebut sebagai permasalahan yang menyebabkan penumpukan pencairan dana APBN pada akhir tahun anggaran adalah kurang dari 50\% responden untuk setiap variabelnya di mana persentase terbesar responden $(23,01 \%)$ terdapat pada keterlambatan penetapan SK Panitia Lelang (Q10).

Tindak lanjut atas permasalahan ini dapat mengacu pada Perpres No. 70 Tahun 2012 tentang Perubahan Kedua atas Peraturan Presiden No. 54 Tahun 2010 tentang Pengadaan Barang/ Jasa Pemerintah, yang menegaskan pelaksanaan pengadaaan barang/ jasa mendahului tahun anggaran. Dengan demikian, SK panitia lelang untuk menggantikan panitia sebelumnya beserta pelaksanaan lelang dapat ditetapkan sebelum memasuki tahun anggaran bersangkutan untuk mengantisipasi panjangnya proses lelang dan pelaksanaan pengadaan.

\subsubsection{Faktor Jadwal Pengadaan}

Responden yang menyatakan setuju dan sangat setuju bahwa empat variabel pembentuk jadwal pengadaan (Q12, Q13, Q14, dan Q21) merupakan masalah yang menyebabkan penumpukan pencairan dana APBN pada akhir tahun anggaran adalah ratarata sebesar 36,73\%. Penentuan HPS (Q13) merupakan masalah dengan persentase responden menyetujui terbanyak dalam faktor ini $(53,98 \%)$.

Guna mendapatkan SDM berkualitas khususnya dalam menentukan HPS, Satker memerlukan pendidikan dan pelatihan sehingga dapat memanfaatkan survey pasar, data kontrak di masa lalu, perhitungan harga satuan, dan referensi lainnya dengan baik yang dapat membantu dalam menentukan HPS. Masalah dengan persentase responden terbanyak kedua $(39,82 \%)$ dalam faktor ini adalah keterlambatan dalam pengesahan dokumen lelang (Q14). Dokumen lelang yang telah diuji dan diseleksi dalam batas waktu yang ditentukan harus segera disahkan sehingga: 1).Kegiatan berikutnya dapat segera ditindaklanjuti, 2).Pemenang lelang dapat segera diumumkan, 3).Pekerjaan sesuai kesepakatan lelang dapat segera dilaksanakan, dan 4).Anggaran yang dialokasikan atasnya dapat segera terserap.

\subsubsection{Faktor Sumber Daya Manusia}

Responden yang menyatakan setuju dan sangat setuju bahwa empat variabel pembentuk faktor SDM (Q6, Q7, Q8, dan Q9) merupakan masalah yang menyebabkan penumpukan pencairan dana APBN pada akhir tahun anggaran adalah rata-rata sebesar $69,25 \%$. Persentase responden yang menyetujui keempat variabel pembentuk faktor SDM sebagai penyebab penumpukan pencairan dana pada akhir tahun anggaran adalah masing-masing lebih dari 50\%.

Rangkap tugas dalam jabatan panitia pengadaan (Q6) seharusnya dihindari sehingga pelaksanaan pengadaan dapat berjalan lebih efektif tanpa 
terganggu adanya benturan kepentingan dan kesibukan karena pekerjaan lainnya. Salah satu solusi yang dapat dilakukan adalah dengan membentuk unit yang khusus menangani pengadaan barang/ jasa. Ketakutan pejabat atas risiko korupsi yang banyak diberitakan terjadi pada bidang pengadaan barang/ jasa (Q7) dapat dieliminasi dengan pendidikan anti korupsi kepada pegawai, sehingga timbulnya kesan bahwa kegiatan pengadaan barang/ jasa berkaitan dengan tindak korupsi dapat dieliminasi. Keengganan menjadi pejabat pengadaan karena tidak seimbangnya risiko dan imbalan (Q8) dapat diatasi dengan meninjau risiko pekerjaan pengadaan barang/ jasa untuk dijadikan sebagai dasar penentuan imbalan yang memadai. Guna menghindari keterbatasan pejabat/ pelaksana pengadaan berserfikat (Q9), Satker hendaknya rutin mengirimkan pegawainya pada pendidikan dan pelatihan yang bersertifikasi pengadaan barang/ jasa pemerintah.

\subsubsection{Faktor Kompetensi}

Responden yang menyatakan setuju dan sangat setuju bahwa tiga variabel pembentuk faktor kompetensi (Q5, Q11, dan Q26) merupakan masalah yang menyebabkan penumpukan pencairan dana APBN pada akhir tahun anggaran adalah rata-rata sebesar 35,99\%. Dua permasalahan dengan persentase responden terbesar yang menyetujui ketiga variabel tersebut sebagai penyebab penumpukan pencairan dana pada akhir tahun anggaran adalah SDM pelaksana pengadaan kurang kompeten (Q5) dan terlambatnya penyusunan jadwal pelaksanaan lelang (Q11).

Guna mengatasi permasalahan SDM pelaksana pengadaan kurang kompeten, Satker dapat mengirimkan pegawainya dalam pendidikan dan pelatihan serta sertifikasi pengadaan barang/ jasa pemerintah. Dengan demikian, SDM satuan kerja tersebut akan meningkat kompetensinya dalam bidang pengadaan barang/ jasa. Selain itu, kompetensi pelaksana pengadaan akan terasah dengan pengalaman yang dihadapi selama melaksanakan pengadaan barang/ jasa. Jadwal pelaksanaan lelang yang terlambat disusun mengakibatkan proses lelang tidak dapat dilaksanakan di awal tahun sehingga baik keseluruhan proses lelang maupun kegiatan pengadaan setelah proses lelang menjadi terhambat. Sebagaimana diatur dalam Perpres No. 70 Tahun 2012 yang mempertegas pelaksanaan pengadaaan yang mendahului tahun anggaran, jadwal pelaksanaan lelang dapat disusun dan pelaksanaan lelang dapat dilakukan sebelum memasuki tahun anggaran bersangkutan.

\subsubsection{Faktor Mutasi Pejabat}

Responden yang menyatakan setuju dan sangat setuju bahwa variabel pembentuk faktor mutasi pejabat, yaitu pejabat/ pegawai pengelola keuangan sering mengalami mutasi (Q28), merupakan masalah yang menyebabkan penumpukan pencairan dana
APBN pada akhir tahun anggaran adalah sebanyak 25,66\% responden. Mutasi pejabat perbendaharaan/ pengelola keuangan terutama pada pertengahan tahun berjalan akan menyebabkan macetnya kegiatan pengadaan dan penyerapan anggaran karena harus menunggu pejabat/ pengelola keuangan yang baru dilantik. Selain itu, umumnya diperlukan penyesuaian atas jabatan baru yang cukup memakan waktu untuk dapat menguasai pelaksanaan pekerjaan. Solusi untuk mengatasi permasalahan ini adalah dengan perbaikan kebijakan mutasi, yaitu melakukan mutasi pejabat/ pengelola keuangan setelah tahun anggaran berakhir dan segala kewajiban pejabat/ pengelola keuangan yang berkaitan dengan pelaksanaan anggaran harus diselesaikan sebelum mutasi dilakukan.

\section{KESIMPULAN DAN SARAN}

Berdasarkan hasil analisis dan pembahasan faktor, penumpukan pencairan dana APBN pada akhir tahun anggaran pada Satker lingkup Kantor Pelayanan Perbendaharaan Negara (KPPN) Jakarta V disebabkan oleh delapan (8) faktor dengan variansi kumulatif sebesar 68,324\%, sedangkan sisanya sebesar $31,676 \%$ dijelaskan oleh faktor selain kedelapan faktor tersebut. Variansi dari kedelapan faktor tersebut menunjukkan besarnya prioritas permasalahan yang harus segera ditangani oleh pembuat kebijakan dengan urutan prioritas, yaitu:

1. Faktor Administrasi Perbendaharaan yang menjelaskan variasi seluruh item yang ada sebesar 27,592\%;

2. Faktor Pelaksanaan Pengadaan yang menjelaskan variasi seluruh item yang ada sebesar 9,693\%;

3. Faktor Perencanaan yang menjelaskan variasi seluruh item yang ada sebesar 7,33\%;

4. Faktor Persyaratan Teknis Pendukung yang menjelaskan variasi seluruh item yang ada sebesar 6,325\%;

5. Faktor Jadwal Pengadaan yang menjelaskan variasi seluruh item yang ada sebesar 5,127\%;

6. Faktor Sumber Daya Manusia yang menjelaskan variasi seluruh item yang ada sebesar 4,643\%;

7. Faktor Kompetensi yang menjelaskan variasi seluruh item yang ada sebesar 4,069\%;

8. Faktor Mutasi Pejabat yang menjelaskan variasi seluruh item yang ada sebesar 3,544\%.

Berdasarkan hasil penelitian dan simpulan tersebut di atas, dapat dikemukakan saran sebagai berikut:

1. Satker perlu melakukan evaluasi berkala atas kesesuaian realisasi dan rencana penarikan dana yang terdapat pada halaman 3 DIPA.

2. Satker perlu meningkatkan disiplin pegawai dengan meningkatkan pengawasan vertikal dan internal serta pemberian insentif.

3. Satker dapat mengurangi adendum kontrak dengan cara memperbaiki evaluasi kebutuhan 
sebelum kontrak disepakati, mengawasi perkembangan pekerjaan pihak ketiga, dan berkomunikasi dengan pihak ketiga secara rutin dalam penyelesaian pekerjaan.

4. Satker perlu melakukan survey pendahuluan atas harga tanah dan kondisi-kondisi yang dapat menghambat proses pembebasan tanah, sehingga permasalahan pembebasan tanah dapat diatasi.

5. Satker perlu lebih teliti dalam menentukan akun kegiatan sehingga sesuai dengan Bagan Akun Standar (BAS).

6. Satker perlu melakukan perencanaan lebih awal dengan data pendukung yang memadai dan mengadakan evaluasi berkala sehingga anggaran yang diusulkan lebih realistis sesuai kebutuhan.

7. Satker dapat menetapkan Surat Keputusan (SK) panitia lelang dan melaksanakan lelang sebelum memasuki tahun anggaran bersangkutan.

8. Satker harus lebih cepat dalam mengesahkan dokumen lelang sehingga kegiatan pengadaan tidak tertunda.

9. Satker perlu membentuk unit khusus yang menangani pengadaan barang/ jasa dan menghindari terjadinya rangkap tugas dan jabatan.

10. Satker dapat memberikan pendidikan anti korupsi dan menawarkan insentif yang memadai.

11. Satker perlu mengusahakan sertifikasi pengadaan barang/ jasa pemerintah untuk para pegawainya.

12. Satker harus memilih pegawai yang kompeten sebagai pelaksana pengadaan barang/ jasa dan menyusun jadwal pelaksanaan lelang lebih awal.

13. Satker perlu memastikan bahwa pejabat/ pengelola keuangan terutama yang berkaitan dengan pelaksanaan anggaran telah menyelesaikan kewajibannya sebelum mutasi dilakukan.

\section{IMPLIKASI DAN KETERBATASAN}

Penulis menyadari penelitian ini masih memiliki keterbatasan yang dapat diperbaiki pada penelitian berikutnya untuk meningkatkan hasil penelitian. Keterbatasan dalam penelitian ini, yaitu:

1. Jumlah responden dalam penelitian relatif sedikit meskipun memenuhi jumlah sampel minimum yang dianjurkan dalam analisis faktor;

2. Penelitian ini hanya berfokus pada belanja barang dan belanja modal;

3. Penelitian ini hanya mengakomodasi jawaban berupa perspektif dari Satker.

\section{DAFTAR PUSTAKA (REFERENCES)}

Arikunto, Suharsimi. (2006). Prosedur Penelitian Suatu Pendekatan Praktik. Edisi Revisi ke-6. Jakarta: Rineka Cipta.

Ghozali, Imam. (2013). Aplikasi Analisis Multivariate Dengan Program IBM SPSS 22 Update PLS Regresi. Edisi ke-7. Semarang: Badan Penerbit Universitas Diponegoro.
Halim, Abdul (Penyunting). (2014). Manajemen Keuangan Sektor Publik: Problematika Penerimaan dan Pengeluaran Pemerintah (Anggaran Pendapatan dan Belanja Negara/ Daerah). Jakarta: Salemba Empat.

Hansen, Don R., dan Maryanne M. Mowen. (2007). Managerial Accounting. 8th edition. Ohio: Thomson Learning South-Western.

Herriyanto, Hendris. (2012). Faktor-Faktor yang Mempengaruhi Keterlambatan Penyerapan Anggaran Belanja pada Satuan Kerja Kementerian/ Lembaga di Wilayah Jakarta. Tesis, Tidak Dipublikasikan, Jakarta: Fakultas Ekonomi, Universitas Indonesia.

Irawan, Prasetya. (2007). Penelitian Kualitatif dan Kuantitatif untuk Ilmu-Ilmu Sosial. Jakarta: DIA FISIP UI.

Kementerian Keuangan. 2014. Laporan Keuangan Pemerintah Pusat Tahun 2013 (Audited).

Kementerian Keuangan. (2014). Nota Keuangan dan APBN Tahun Anggaran 2014.

Kementerian Keuangan. (2014). Pokok-Pokok Siklus APBN di Indonesia: Penyusunan Konsep Kebijakan dan Kapasitas Fiskal Sebagai Langkah Awal. Jakarta: Direktorat Jenderal Anggaran.

Kementerian Keuangan. (2015). Nota Keuangan dan APBN Perubahan Tahun Anggaran 2015.

Kuswoyo, Iwan Dwi. (2011). “Analisis atas FaktorFaktor yang Menyebabkan Terkonsentrasinya Penyerapan Anggaran Belanja di Akhir Tahun Anggaran (Studi pada Satuan Kerja di Wilayah KPPN Kediri)". Tesis, Tidak Dipublikasikan, Yogyakarta: Fakultas Ekonomika dan Bisnis, Universitas Gadjah Mada.

Miliasih, Retno. (2012). “Analisis Keterlambatan Penyerapan Anggaran Belanja Satuan Kerja Kementerian/ Lembaga TA 2010 di Wilayah Pembayaran KPPN Pekanbaru", Tesis, Tidak Dipublikasikan, Jakarta: Fakultas Ekonomi, Universitas Indonesia.

Nugroho, Mashudi Adi. (2013). "Analisis FaktorFaktor yang Menyebabkan Penumpukan Pencairan Dana APBN di Akhir Tahun (Studi Kasus di KPPN Malang", Skripsi, Tidak Dipublikasikan, Malang: Fakultas Ekonomi dan Bisnis, Universitas Brawijaya.

Priatno, Prasetyo Adi. (2013). "Analisis FaktorFaktor yang Mempengaruhi Penyerapan Anggaran pada Satuan Kerja Lingkup Pembayaran KPPN Blitar", Jurnal Ilmiah Mahasiswa FEB. Vol. 1, No. 2, Malang: Fakultas Ekonomi dan Bisnis, Universitas Brawijaya.

Santoso, Singgih. (2010). Statistik Multivariat: Konsep dan Aplikasi dengan SPSS. Jakarta: Elex Media Komputindo. 
Sekaran, Uma dan Roger Bougie. (2013). Research Methods for Business: A Skill-Building Approach, Sixth Edition. United Kingdom: John Wiley \& Sons Ltd.

Siregar, Syofian. (2013). Metode Penelitian Kuantitatif: Dilengkapi Perbandingan Perhitungan Manual \& SPSS. Jakarta: Kencana Prenada Media Group.

Tim Penyusun BPPK. (2004). Dasar-Dasar Keuangan Publik. Jakarta: Badan Pendidikan dan Pelatihan Keuangan (BPPK).

Widarjono, Agus. (2015). Analisis Multivariat Terapan: Dengan Program SPSS, AMOS, dan SMARTPLS. Edisi ke-3. Yogyakarta: UPP STIM YKPN.

\section{Peraturan Perundang-undangan}

Undang-Undang No. 17 Tahun 2003 tentang Keuangan Negara.

Undang-Undang No. 27 Tahun 2014 tentang Anggaran Pendapatan dan Belanja Negara Tahun 2015.

Peraturan Pemerintah Nomor 45 Tahun 2013 tentang Tata Cara Pelaksanaan Anggaran Pendapatan dan Belanja Negara.

Peraturan Presiden Nomor 54 tahun 2010 tentang Pengadaan Barang/ Jasa Pemerintah.

Peraturan Presiden Nomor 70 tahun 2012 tentang Perubahan Kedua atas Peraturan Presiden Nomor 54 Tahun 2010 tentang Pengadaan Barang/ Jasa Pemerintah.

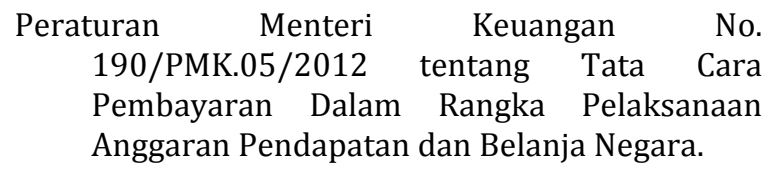

Peraturan Menteri Keuangan No.
171/PMK.02/2013 tentang Petunjuk Penyusunan dan Pengesahan Daftar Isian Pelaksanaan Anggaran.

Peraturan Menteri Keuangan No. 154/PMK.05/2014 tentang Pelaksanaan Sistem Perbendaharaan dan Anggaran Negara.

Peraturan Menteri
214/PMK.05/2013
Standar.

Peraturan Menteri Keuangan No. 277/PMK.05/2014 tentang Rencana Penarikan Dana, Rencana Penerimaan Dana, dan Perencanaan Kas.

\section{Dokumen dan Sumber Lain}

Kantor Pelayanan Perbendaharaan Negara Jakarta V. (2014). Bahan Sosialisasi SPAN SAKTI KPPN Jakarta $V$. 